\title{
Research on Rural Economic Development in Scattered Minority Areas-A Case Study of Maojiatan Hui Uygur Township
}

\author{
Xingtai Li \\ School of Economics, Southwest Minzu University, Chengdu, China \\ Email: 1312849279@qq.com
}

How to cite this paper: Li, X.T. (2021) Research on Rural Economic Development in Scattered Minority Areas-A Case Study of Maojiatan Hui Uygur Township. Open Access Library Journal, 8: e7658. https://doi.org/10.4236/oalib.1107658

Received: June 18, 2021

Accepted: July 6, 2021

Published: July 9, 2021

Copyright $\odot 2021$ by author(s) and Open Access Library Inc.

This work is licensed under the Creative Commons Attribution International License (CC BY 4.0)

http://creativecommons.org/licenses/by/4.0/

\section{(c) (i) Open Access}

\begin{abstract}
Rural economy is the smallest range of regional economy, which belongs to the most basic link in the system of regional division of labor. It is a regional economy with a certain scale, clear leading industries, prominent industrial characteristics and certain radiation power. Taking small towns as the carrier, rural economy can promote the development of local economy by developing characteristic economy or pillar industries, giving full play to rural resource advantages or comparative advantages, and cultivating backbone enterprises and economic growth points. Maojiatan Hui and Uygur township as a scattered area of ethnic minorities, its industrial structure is unreasonable, coupled with the weak economic foundation, so that there is no breakthrough in the development of this township, how to make its characteristic industries develop is the focus of our research.
\end{abstract}

\section{Subject Areas \\ Development Economics}

\section{Keywords}

Maojiatan Hui and Uygur Township, Rural Economy, Scattered Areas of Ethnic Minorities

\section{Introduction}

In the development goal put forward in the 16th National Congress of the Communist Party of China, we should concentrate our efforts in the first two decades of the 21st century to build a well-off society of a higher level that benefits more than one billion people in an all-round way and build a new socialist country- 
side, to achieve these goals, the difficulty lies in the countryside, and the key lies in the farmers. To solve this problem, we must first devote ourselves to the development of rural economy.

When it comes to rural economy, the first thing we think about is the development of rural economy. Since the 19th National Congress of the Communist Party of China, the country has put forward the strategy of Rural Revitalization. Agricultural and rural issues are the fundamental issues related to the national economy and people's livelihood, and the three rural issues are the top priority of the party's work. In order to achieve the development of rural economy, we must achieve the modernization of agriculture and rural areas. How to achieve the high-quality development of rural economy has become a hot topic of current scholars. At present, the academic community mainly discusses the support of characteristic industries for the development of rural economy, but ignores the weak economic foundation of ethnic areas, and the financial difficulty is also a big problem. Therefore, this paper not only needs to analyze the development of characteristic industries, but also needs to analyze the financial problem.

\section{General Situation of Economic Development in Maojiatan Hui and Uygur Township}

\subsection{Geographical Location}

Maojiatan Hui and Uygur township is located in the west of Hanshou County, Hunan Province. The north of maojiatan township is flat, and the south is hilly. Xiejiapu River, cangshui and langshui run from north to south. CangMao highway, 319 National Highway, Shichang Railway and changchanggao road cross the territory. The township covers a total area of 53.05 square kilometers and has a permanent population of about 26,000 of which 8859 are Hui, Uygur, Tujia, Miao and other ethnic minorities, accounting for $33.26 \%$ of the total population. Maojiatan is located in subtropical monsoon climate with obvious seasonality [1].

\subsection{Current Situation of Economic Development}

Maojiatan Township mainly focuses on rice cultivation, and has built a 10,000 $\mathrm{mu}$ high-quality rice base. The unit yield of late rice is more than 1000 Jin. In addition, cotton, bamboo, fruit, lotus root, seedlings and flowers, turtle, fresh fish, meat and poultry are also indispensable agricultural products of maojiatan township. The agricultural production and product quality of maojiatan township are improved year by year under the drive of agricultural industrialization. In terms of characteristic industries, Egyptian sugar orange is a myth of the development of agricultural industry in maojiatan Hui and Uygur township. Relying on the scientific and technological strength of Sanli company of Hunan Xingxiang science and Technology Park, the township has built nearly $2000 \mathrm{mu}$ of high-quality and pollution-free Egyptian sugar orange production base. In recent years, the seedling and flower industry has also become an important industry for farmers to increase their income and become rich, a total of $300 \mathrm{mu}$ of 
high-quality seedling and flower production base has been established in the township [2].

With the rapid growth of agriculture, the development of township enterprises and private economy keeps pace with the times. A number of private enterprises such as rice processing enterprises and oil chemical enterprises have become the pillar industries of maojiatan Hui Uygur township. Maojiatan also successfully established one pole factory, four prefabrication plants, one metal smelter, two red brick factories, one colored tile factory, seven small tile factories, 21 rice factories, and three sand egg mining fields.

\section{Analysis on the Problems and Causes of Rural Economic Development in Maoba Town}

\subsection{Main Problems}

\section{1) Unreasonable economic structure}

Although maojiatan township is a traditional agricultural township, the productivity of the primary industry is low, the level of agricultural industrialization is not high, the speed of economic growth is slow, the mechanization rate of local farming is less than $70 \%$, and the land circulation rate is low. Secondly, although the secondary industry of maojiatan township is developing rapidly, its productivity is low. Most of them are small-scale enterprises, and most of them are products with high pollution, high energy consumption and low production value. The economic benefits are not high and the local environment is seriously damaged. Because maojiatan township is a typical agricultural township, the development level of the tertiary industry is not high, and its output value only accounts for $13 \%$ of the total output value of maojiatan township, the development is relatively backward, and the contribution rate to the economy is not obvious.

\section{2) Lack of funds}

The more economically developed areas are, the more investment they attract. The more economically underdeveloped areas are the less people want to develop here. In the long run, the poorer the poor are, the richer the rich are [3]. Maojiatan is an ordinary town in Hunan Province. There are neither charming scenic spots nor rich mineral resources. No enterprises are willing to invest and lack of external funds. In addition, due to the limited fiscal revenue, the actual amount of government investment in local public facilities, education, human settlements and other aspects is not very large.

\section{3) Lack of leading enterprises}

We all know that the development of a region cannot be separated from the growth pole, so it can not be affected by leading enterprises. Although maojiatan township has Egyptian sugar orange as a local characteristic industry, its driving force is not obvious, mainly because of its low industrial structure, no deep processing of sugar orange, but simple collection and sales, resulting in low income. Secondly, other crops planted in maojiatan have no scale effect, and many of the crops produced are self-sufficient and not sold to other places. To find a 
breakthrough in the development of maojiatan, we must develop our leading enterprises.

\subsection{Analysis of the Causes of the Problems}

\section{1) Lack of leaders}

The leaders will lead the development of a region, while maojiatan township has neither the government nor enterprises or individuals to take the lead. Therefore, we can find that many businesses in maojiatan township are operated by themselves, and the scale of self-employed business is small. Most of the customers they face are customers of their own township, which leads to low economic benefits. Without a township leader, the development of a township is like a headless fly.

\section{2) Not making full use of national policy}

According to the provisions of the people's Republic of China on the protection of the rights and interests of scattered ethnic minorities, the relevant departments should give priority to the care and support to ethnic townships and administrative areas inhabited by scattered ethnic minorities in arranging economic construction projects and special funds, loans, carrying out counterpart support and economic and technological cooperation. From the legal point of view, as long as maojiatan township has independent entrepreneurs, local investment enterprises, corresponding loans and taxes will be given benefits. However, from the current situation, people do not fully understand the law, nor do they have the courage to start their own business. Maojiatan has a large area of cultivated land, and according to the "cultivated land protection law", houses can not be built on the cultivated land, so there is no big factory built in maojiatan township.

\section{3) Lack of advanced technology}

Maojiatan is now extensive production and processing, and most of them are manual production, and the technical level is low. This not only leads to high processing cost, low production efficiency, but also reduces economic benefits. The local Egyptian sugar orange lacks technical links from picking to selling, and it does not deep process the orange into other finished products, such as making sugar orange into canned orange, orange peel into medicine, or other products. These can improve the technology content of sugar orange and improve the income. But maojiatan township has no relevant technology to do so.

\section{Countermeasures and Suggestions on Speeding up the Rural Economic Development of Hui and Uygur in Maojiatan}

\subsection{Speed up the Development of Modern Agriculture}

1) Pay attention to structural adjustment and further increase farmers' income

Maojiatan township is a traditional agricultural township. In order to realize 
the economic development of scattered minority areas, it is necessary to develop agriculture with local characteristics and realize the modernization of agriculture and rural areas. Maojiatan township needs to adjust the agricultural and rural structure, expand and strengthen the characteristic industries such as high-quality rice, sugar orange, rice shrimp breeding, flowers and seedlings, and strive to form an industrial development pattern of one village, one industry and one product [4]. Organize farmers to carry out labor skills training, reasonably guide the export of labor services, and broaden the channels for farmers to increase their income. Establish agricultural professional cooperative organizations, explore long-term rural construction management mechanism.

\section{2) Focus on transforming traditional agriculture}

First, we should use market rules to guide agricultural development, guide farmers, agricultural production organizations and agricultural product processing enterprises, and strengthen the collection of agricultural market information. Second, we should develop agriculture with the concept of industry. Around the requirements of industrial production, we should integrate land and product resources, actively produce raw materials for industrial production, and gradually develop agriculture into a raw material source industry for industrial production. Improve the processing technology, and constantly eliminate the traditional processing and workshop processing with rough technology, extensive management, high resource consumption and low added value, so as to make the agricultural products processing industry step into the development track of low consumption, high technology and high added value.

\section{3) To be bigger and stronger and form brand effect}

At present, to achieve a breakthrough in agriculture, standardization is the key. Although maojiatan's characteristic agricultural products are booming, it is still far from achieving its own brand effect. Maojiatan's sugar oranges, flowers and characteristic rice have not yet achieved standardized production and operation. Many of them are retail investors or small private enterprises. The local government can support leading enterprises to implement processing standards, realize the docking of planting standard and processing standard image.

\subsection{Attracting Foreign Investment and Encouraging Entrepreneurship}

\section{1) Attracting foreign investment}

Maojiatan township lacks the motivation to start a business. The government can appropriately relax the requirements for starting a business, encourage enterprises to invest and start a business in maojiatan township, relax loans for enterprises that invest and build factories, and reduce taxes. Maojiatan township can also refer to the talent entrepreneurship support policy of Caoxian county. If the enterprise tax exceeds a certain value, the rent will be reduced. Maojiatan is lack of talent entrepreneurship support policy, outside enterprises rarely invest in maojiatan factory, so the government needs to help. 


\section{2) Encourage entrepreneurship and make full use of ethnic policies}

In addition to attracting outside investment, it is also a very important choice to encourage local people to start businesses. At present, maojiatan lacks the motivation to start businesses. The main reason is that people do not understand the ethnic policies and lack the government's encouragement and support. People are willing to venture capital in the first tier cities because of government support, large number of customers and the lack of entrepreneurial environment in maojiatan township. Naturally, people dare not start their own businesses. Even if there are ethnic preferential policies, local people still choose to go out to work. The government needs to come forward, widely publicize and formulate corresponding policies to encourage people to start businesses [5].

\subsection{Insist on Scientific Development and High Quality Development}

\section{1) Insist on Sustainable Development}

The development of economy will inevitably bring pollution. At present, water pollution has become the main source of local pollution. Reasonable development and adhering to the concept of "green water and green mountains are golden mountains and silver mountains". At present, the local sewage treatment work is in full swing, but the pollution should be paid attention to from the source, the government should strengthen supervision, pay close attention to the fish who have missed the net, and the economic development should be on the green road [6].

\section{2) Learn advanced technology and introduce advanced equipment}

In addition to policy support, it is necessary to introduce advanced technology and equipment. For example, if sugar orange needs to be further processed into canned food, it needs canned food processing equipment. Sugar orange production can also learn from other people's advanced production management technology and grow scientifically. In addition to sugar orange, other local crops should be planted scientifically and standardized to maximize the quality and yield of planting.

\section{Conclusion}

At present, the problems of maojiatan's development lie in the unreasonable economic structure, lack of funds and leading enterprises. The reasons for these problems lie in the lack of leaders, making full use of national policies and advanced technology. To solve these problems, I should speed up the development of modern agriculture, attract foreign investment, encourage entrepreneurship, adhere to scientific development and high-quality development. The economic foundation of villages and towns is weak, and the policy support of maojiatan township, a scattered minority area, is of great help to the development of rural economy. Through the analysis of the economic development problems of maojiatan township, this paper provides suggestions for the future development of 
maojiatan township, hoping to provide help for the development of maojiatan township.

\section{Funding}

This paper is supported by Southwest Minzu University's Innovative Research Project for Postgraduates in 2021 (No. CX2021SP16).

\section{Conflicts of Interest}

The author declares no conflicts of interest.

\section{References}

[1] Xiao, M.Q. and Tong, X. (2019) Research on Targeted Poverty Alleviation in Maojiatan Hui and Uygur Township of Hunan Province. Science \& Technology Information, 17, 203-204.

[2] Hu, Z.D. (1993) Joint Stock Cooperative System is an Important Way to Realize the Rapid Development of Township Enterprises-A Survey of Joint Stock Cooperative Enterprises in Tinzui and Maojiatan Townships. Social Sciences in Hunan, 6, 64-66.

[3] Wang, X.L. (2014) Research on Rural Economic Development in Underdeveloped Areas-A Case Study of Maoba Town, Xuanhan County, Dazhou City. China Collective Economy, 30, 26-27.

[4] Zhou, Z.P. (2015) Making Rural Economy Bigger and Stronger. Farmers' Daily. http://szb.farmer.com.cn/2015/20150808/20150808_003/20150808_003_3.htm

[5] Feng, S., Qiao, L.Y. and Yin, G. (2012) Thoughts and Suggestions on Rural Economic Development Survey. Hebei Enterprises, 24, 50-51.

[6] State Planning Commission Training Center (2000) County Economic Development and Planning. China Planning Press, Beijing. 